\title{
Health and Safety at Work in the Time of Covid-19: A Social Europe Reckoning?
}

\author{
Published in European Journal of Risk Regulation \\ Link to final version: https://doi.org/10.1017/err.2020.86
}

Konstantinos Alexandris Polomarkakis*

\begin{abstract}
The shortcomings in the handling of Covid-19 highlighted the salience of health and safety at work and fuelled discussions surrounding the desirability of a European Health Union. This article conceptualises occupational health and safety at EU level as a key driver for the creation of a European Health Union. Through recourse to the area's roots and its relevance to the tackling of the Covid-19 pandemic, the benefits of putting occupational health and safety in the driving seat are set out. For the implications of keeping a healthy workforce are acute, from both a social and public health perspective, especially in the time of a pandemic. Relying on a reflective approach that goes beyond the status quo, the article offers pragmatic yet imaginative proposals for strengthening the occupational health and safety acquis. The proposals act as the blueprint for health and safety in the workplace to lay the foundation for a European Health Union and advance the social dimension of the EU.
\end{abstract}

\section{Introduction}

As Europe, much like the rest of the world, felt the impact of Covid-19, its large-scale workplaces, factories, abattoirs and warehouses, were singled out as transmission hotspots. ${ }^{1}$ Workers and trade unions protested over breaches of their occupational health and safety. ${ }^{2}$ Yet, in some instances, new outbreaks keep popping up in those exact same places. ${ }^{3}$ Not only that, but, alongside these occurrences, the world also witnessed the plight of healthcare professionals that were offered inadequate Personal Protective Equipment (PPE). ${ }^{4}$ The afore-mentioned occasions, triggered by the ongoing pandemic, demonstrably underline the need to guarantee health and safety at work, not least to avoid a resurgence of infections. They also highlight the peculiar nature of occupational health and safety, which oscillates between social policy and public health.

\footnotetext{
* Lecturer in Socio-Legal Studies, Brunel Law School, Brunel University London, UK; email: Konstantinos.AlexandrisPolomarkakis@brunel.ac.uk. I would like to thank the anonymous reviewers for their comments. All errors remain my own.

${ }^{1}$ E Terazono and A Schipani, "How slaughterhouses became breeding grounds for coronavirus" (Financial Times, 8 June 2020) <https://www.ft.com/content/de2ca3f6-cd63-486a-a727-069762ca4a2a $>$ (last accessed 29 June 2020).

2 S Drew, "At Amazon, safety and wellbeing do not come first, Nanterre Tribunal rules" (UK Labour Law Blog, 21 April 2020)<https://uklabourlawblog.com/2020/04/21/at-amazon-safety-and-wellbeing-do-not-come-firstnanterre-tribunal-rules-by-sandhya-drew/> (last accessed 29 June 2020).

${ }^{3}$ M Arnold, "Abattoir coronavirus outbreak triggers infections surge in Germany" (Financial Times, 21 June 2020) <https://www.ft.com/content/057e861b-ef35-418d-9d16-81d2a0219212> (last accessed 29 June 2020); P Nilsson and D Lee, "Amazon workers strike in Germany over virus safety" (Financial Times, 29 June 2020) $<$ https://www.ft.com/content/3d1d14f3-ae0e-4ed4-ba26-9b357071c699> (last accessed 29 June 2020).

4 J Robottom, "The legal rights of healthcare workers to personal protective equipment during the COVID-19 pandemic" (UK Labour Law Blog, 13 April 2020) <https://uklabourlawblog.com/2020/04/13/the-legal-rights-ofhealthcare-workers-to-personal-protective-equipment-during-the-covid-19-pandemic-by-james-robottom/> (last accessed 29 June 2020).
} 
Ever since the founding Treaty of Rome, protection against occupational accidents, diseases and hazards, as well as workplace hygiene were clearly incorporated therein as the constituent elements of Social Europe. ${ }^{5}$ It should come as no surprise, then, that the area has seen comprehensive legislative and policy initiatives at EU level, long before other aspects of social policy or public health. Its long-standing institutional embeddedness rendered occupational health and safety a fait accompli. Despite the relatively early Europeanisation of the area, there has been some sort of hibernation in pushing things forward recently. Covid-19 exposed the deficiencies of the status quo, and at the same time showcased the salience of foolproof occupational health and safety regulation. That way, the ambitions for a stronger Social Europe, but also for a European Health Union, would come a step closer to materialising.

This article sets out to explore the meaning of health and safety at work in the time of Covid19 and its contribution to the creation of a European Health Union. It kicks off by pondering over the place of occupational health and safety in the European Health Union debate. Next, it lays down the fundamentals of occupational health and safety at EU level, looking back at its origins and tracing its development over time. The article continues by elaborating on the aspects of health and safety in the workplace most relevant to tackling the Covid-19 pandemic, including the -muted- recent initiatives. These are then compared and contrasted with the more constrained domain of public health governance. This serves to highlight the potential of health and safety in the workplace as a malleable yet long-standing area of EU policy-making, that could easily form the backbone of a European Health Union. Following that comes a discussion of potential reforms to regenerate occupational health and safety's importance in the time of Covid-19. The article reimagines the relevant acquis and contemplates ways to enhance the protection offered as well as its adaptability. It concludes by arguing that Covid-19 could act as a catalyst that brings Social Europe, to which health and safety at work belongs, back from obscurity, moving it to the forefront of conversations surrounding the formulation of a European Health Union.

\section{Occupational Health and Safety in a European Health Union}

Talks about the creation of a European Health Union abound. What better way to tackle ongoing and future pandemics than to strengthen coordination and approximate public health policies and strategies at EU level. If anything, Covid-19 has shown that transnational cooperation is key. Health and safety in the workplace does not feature among the areas of EU competence that are traditionally perceived as the foundations of EU public health governance. On the contrary, it has been primarily associated with Social Europe, and EU labour law in particular. How does it, then, become relevant in the European Health Union debate? Is it not that a European Health Union only entails a pimped-up version of EU public health governance?

Calls for a European Health Union have been amplified in the course of the ongoing pandemic. Various organisations and think tanks have advocated for actions towards that direction. This is exemplified at institutional level by a European Parliament resolution on the future EU public health strategy for Covid-19, the first point of which makes explicit reference to the creation of a European Health Union. ${ }^{6}$ Although it is outside the scope of this article to provide a

\footnotetext{
${ }^{5}$ Art. 118 EEC. Note that the term Social Europe refers to the area of EU competence titled Social Policy in the Treaties.

${ }^{6}$ European Parliament Resolution of 10 July 2020 on the EU's public health strategy post-COVID-19 (2020/2691(RSP)).
} 
definition of the term, most of the afore-mentioned calls are based on the premise of a stronger public health component of the EU, mentioning health and safety in the workplace only in passing, if at all. Indeed, the much lauded EU4Health Programme had monopolised the field, only for its funding to be substantially trimmed down later in July 2020 as one of the collaterals in the Multiannual Financial Framework (MFF) negotiations. ${ }^{7}$

Other contributions in this issue engage extensively with the specifics of a European Health Union. For the purposes of this article, a more liberal approach to the delineation of the term European Health Union is espoused; one that brings the marginalised -in this contextoccupational health and safety to the forefront of discussions. Simply put, ensuring occupational health and safety, especially in the time of a pandemic, is bound to have an inherently positive impact on the public health front too. After all, health and safety at work might not be the most obvious example, but this does not mean it is not an essential element of a fully-realised European Health Union. ${ }^{8}$ For a healthy workforce is a sign of a healthy population along with success in preventing as well as containing communicable diseases and public health emergencies alike.

The term European Health Union lacks a rigid definition. Its links to public health might be obvious, but that does not mean that its scope cannot be conceptually reinvented for occupational health and safety to no longer sit at the fringes of proposed action. Conceptualising European Health Union as an umbrella term or framework, emancipated from its exclusive association to EU public health governance -and competence, is conducive to the inclusion of occupational health and safety therein. Rejecting the view of complementary areas of EU action as silos is not unheard of. Looking at the European Pillar of Social Rights, for example, health care is featured as one of its principles, even though it does not belong to a stricto sensu Social Europe. ${ }^{9}$ In other words, there have already been EU initiatives that draw on diverse EU policy areas.

In an era where bold and innovative actions are needed, allowing the co-existence of competence areas under a wider framework of action, such as that of a European Health Union, is likely to prove beneficial. Naturally, arguments to the contrary that invoke, for example, the need for simplicity by sticking to the EU public health competence could be raised. Given the MFF's financial blow to the EU4Health Programme, the benefits of encompassing another area of action with distinct competences and processes in order to lay the foundation of an effective overarching scheme may as well outweigh any negatives. If anything, European Health Union would enjoy a diverse toolkit of legal bases -and competences, adapted to its constituent elements.

Under this broad conceptualisation of the term European Health Union, narrowly defined public health measures would remain under the EU public health competence, whilst the social policy title would still be used for occupational health and safety actions. Yet, crossfertilisation and a dialogue between these overlapping policy areas are expected to enhance the quality of the proposed measures. Bringing occupational health and safety under the umbrella of a European Health Union does not equal its removal from Social Europe. Instead, it allows for its strong public health implications to be assessed and shaped in a closely related setting

\footnotetext{
${ }^{7}$ Funding dropped from $€ 9.4$ billion to $€ 1.7$ billion prompting the reaction of the European Parliament. European Parliament Resolution of 23 July 2020 on the conclusions of the extraordinary European Council meeting of 1721 July 2020 (2020/2732(RSP)).

${ }^{8}$ Mutatis mutandis, one can look at Art. 2 of the Constitution of the World Health Organization.

${ }^{9}$ Principle 16 European Pillar of Social Rights.
} 
too, that of a European Health Union. In turn, the latter would be empowered through tangible improvements in occupational health and safety, validating their interdependence.

The article's discussion of occupational health and safety as a core component of a European Health Union is based on a normative framing of the term that bears resemblance to what has been described above. This envisions European Health Union as an umbrella term, a framework wider than public health competence, which incorporates the latter and transcends various traditional competence fields. Conceptually, a European Health Union has much more to gain by also relying on other areas closely linked to public health, such as health and safety in the workplace. The remainder of the article does not dwell on the definitional aspects of a European Health Union, which nonetheless thought was prudent to briefly elucidate in this section. It focuses instead on how occupational health and safety can feature, thrive and drive this broadly construed European Health Union.

\section{The Occupational Health and Safety Acquis: From Past to Present to Covid-19}

Unlike public health, which became officially part of the EU competences with the Treaty of Maastricht in 1993, ${ }^{10}$ occupational health and safety was included in the Treaties ever since the Treaty of Rome in 1957 as a constituent element of the Social Policy title. ${ }^{11}$ This is significant in itself, considering the emphasis of the Treaty on the economic aspects of European integration, which resulted in a lacklustre social dimension. ${ }^{12}$ It was initially hoped that achieving economic prosperity would have led to social development. ${ }^{13}$ Although the development of Social Europe has given rise to the alleged fundamental asymmetry between the economic and the social, ${ }^{14}$ health and safety in the workplace is the most highly regulated -and harmonised- area of the social acquis.

Coming back to the Treaty of Rome, the then Article 118EEC (now 156 TFEU), much like the rest of the title, was of a largely symbolic and programmatic character, without stipulating any substantial involvement of the European institutions in the policy process. ${ }^{15}$ Indeed, regarding the areas of Article 118 EEC, health and safety at work included, the Commission could only intervene in order to publish studies and opinions, promote close cooperation and coordinate appropriate action between the Member States. ${ }^{16}$ The Court of Justice of the EU (CJEU) confirmed that under the said Article, the Commission's role was merely procedural 'and cannot prevent the Member States from implementing drafts, agreements and measures which it might consider not to be in conformity with [Union] policies and actions' ${ }^{17}$ It is clear that the Member States had the final say in matters of Social Europe, the then Community lacking any formal supranational competence. ${ }^{18}$

\footnotetext{
${ }^{10}$ With the introduction of what is now Art. 168 TFEU.

${ }^{11}$ Art. 118 EEC (now 156 TFEU). It was also featured in the preceding Economic Coal and Steel Community.

12 O Kahn-Freud, "Social Policy and the Common Market" (1961) 32(4) The Political Quarterly 341.

${ }^{13}$ L Hantrais, Social Policy in the European Union (1st edn, Basingstoke, MacMillan 1995) pp. 1-2.

${ }^{14}$ F Scharpf, "The Double Asymmetry of European Integration; Or: Why the EU Cannot Be a Social Market Economy" (2009) MPIfG Working Paper No. 09/12.

${ }^{15} \mathrm{~J}$ Kenner, EU Employment Law: From Rome to Amsterdam and. Beyond (Oxford, Hart Publishing 2003) p. 6.

${ }^{16}$ C Barnard, EU Employment Law (Oxford, Oxford University Press 2012) p. 4.

17 Cases C-281/85, C-283/85, C-285/85 and C-287/85, Germany and others $v$ Commission [1987] ECLI:EU:C:1987:351.

${ }^{18}$ G Majone, "The European Community Between Social Policy and Social Regulation" (1993) 31(2) Journal of Common Market Studies 153, 154.
} 
A consequence of the reliance on Member State action is the absence of concrete initiatives in the area until the mid-1970s. In the meantime, accidents at work and occupational diseases were on the rise, giving impetus for further -more effective- action, manifested in the contents of the 1974 Social Action programme. ${ }^{19}$ This was followed by two specific action programmes on health and safety at work, ${ }^{20}$ which spurred the first incarnations of a series of occupational health and safety Directives. ${ }^{21}$ To overcome the obstacle posed by the lack of explicit EU competence therein, the institutions had to rely on the general provision of Article $100 \mathrm{EEC}$ (now 114 TFEU) on the approximation of laws affecting the functioning of the internal market. ${ }^{22}$ This is similar to the pre-Action programme days, where the field was regulated indirectly by legislative instruments adopted under other titles. ${ }^{23}$

A watershed moment for the legal aspect of occupational health and safety at EU level was the enactment of the Single European Act (SEA). More specifically, SEA detached the need for measures in the area to be adopted according to the workarounds mentioned in the previous paragraph. The newly introduced Article 118a EEC (now Art 153 TFEU) enabled the adoption of Directives laying down minimum standards and encouraging improvements on health and safety at work by the Council under qualified majority. ${ }^{24}$ The Commission did not waste time in taking advantage of the new provision under the aegis of the 1988 Programme on Safety, Hygiene and Health at Work. ${ }^{25}$ The backbone of those actions was undoubtedly the Framework Directive 89/391/EEC. Its adoption was of great significance, since it enhanced the protection afforded by the Framework Directive 80/1107/EEC by expanding the ambit of legislative intervention and establishing additional guarantees such as duties for the employer. ${ }^{26}$ Moreover, its rather general wording and scope meant that the specifics, particularly those of technical nature, were to be dealt with by a series of follow-up Directives. ${ }^{27}$

The Framework Directive remains the centrepiece of EU legislative action in the area. The broad definitions of the core concepts of worker and employer ensure a wide scope of application and adaptability to changes in industrial relations. ${ }^{28}$ Moreover, the Directive fosters the adoption of protective and preventative measures, with the employer bearing the costs, and creates various duties. ${ }^{29}$ Neal identified six types of employer duties: awareness; direct action to ensure health and safety; strategic planning to avoid risks; training and direction of the workforce; information, consultation and involvement of the workforce; and recording and

${ }^{19} \mathrm{AC}$ Neal and FB Wright, The European Communities' Health and Safety Legislation (London, Chapman \& Hall 1992).

${ }^{20}$ Ibid. See also: C Barnard, supra, note 17, pp. 503-505.

${ }^{21}$ Directive 77/576/EEC of 25 July 1977 on the approximation of the laws, regulations and administrative provisions of the Member States relating to the provision of safety signs at places of work; Directive 78/610/EEC of 29 June 1978 on the approximation of the laws, regulations and administrative provisions of the Member States on the protection of the health of workers exposed to vinyl chloride monomer; Framework Directive 80/1107/EEC of 27 November 1980 on the protection of workers from the risks related to exposure to chemical, physical and biological agents at work, Art 8 of which led to the enactment of more specialised Directives.

${ }^{22}$ G Majone, supra, note 19.

${ }^{23}$ Regulation 543/69/EEC of 25 March 1969 on the harmonisation of certain social legislation relating to road transport and Council Regulation (EEC) No 1463/70 on the introduction of recording equipment (tachographs) in road haulage, adopted under Art 75 EEC of the Transport title.

${ }^{24}$ C Barnard, supra, note 17, p. 50; J Kenner, supra, note 16, p. 95; G Majone, supra, note 19.

${ }^{25}$ AC Neal and FB Wright, supra, note 20, pp. 13-14.

${ }^{26} \mathrm{Ibid}, 17$.

${ }^{27}$ Operating similarly to Framework Directive 80/1107/EEC. C Barnard, supra, note 10, p. 551.

${ }^{28}$ M Biagi, "From Conflict to Participation in Safety: Industrial Relations and the Working Environment in Europe 1992" (1990) 6(2) The International Journal of Comparative Labour Law and Industrial Relations 67.

${ }^{29}$ Arts. 5 and 6 Directive 89/391/EEC. 
notification. ${ }^{30}$ Just by looking at those duties alone, the value of the Framework Directive for ensuring the protection of the workforce in the midst of a pandemic is crystal clear. If anything, it makes it even more salient for employers to comply with their duties.

As mentioned above, a twin-track approach is followed insofar as the regulation of health and safety at work is concerned, where the overarching legislative piece is accompanied by numerous technical or specific ones. ${ }^{31}$ Accordingly, the Framework Directive spurred Directives covering matters of workplace layout, equipment used, exposure to hazardous substances, as well as sectoral measures, the enactment of which spans several decades. ${ }^{32}$ These often tackle issues that fall into the more narrow -and literal- interpretation of health and safety at work, relating to 'risk assessment, preventing accidents at work, maintaining a hygienic working environment and combating industrial diseases'. ${ }^{33}$ They are complemented by measures referring to areas falling into a more expansive understanding of occupational health and safety, such as the Working Time Directive, which seek to improve a wider array of working conditions that can impact on health and safety. ${ }^{34}$ Both are relevant in the case of Covid-19. Strict compliance with the narrow understanding would shield the workforce from the virus, whereas respecting limitations on working time would contain instances of excessive overworking, one of the pandemic's 'side-effects'.

In the decades following the Framework Directive, apart from follow-up legislation on the basis of Article 16(1) thereof, or the occasional codification and updating, the core of the traditional understanding of occupational health and safety remained largely static. The rise of soft law, which affected much of Social Europe, meant that occupational health and safety followed a comparable trajectory, with Recommendations and Strategies issued by the Commission. ${ }^{35}$ Moreover, the European Agency for Safety and Health at Work was inaugurated in $1994 .{ }^{36}$ The advent of 2000 saw health and safety being protected as part of a person's working conditions in the Charter of Fundamental Rights of the EU (CFREU). ${ }^{37}$ The right to a high level of protection of occupational health and safety was also included in the latest reforms surrounding the European Pillar of Social Rights. ${ }^{38}$ Although the latter two are signals of a rights-based approach to the area, opening up a lot of opportunities, it will be argued below that their potential has not been realised yet.

Following from the discussion above, occupational health and safety has proved to be a burgeoning area of EU action despite the peculiar position of the social dimension, especially at the beginning of the EU project. It is true that the early regulation of occupation health and safety at EU level was driven mainly by economic objectives. A level playing field was created among the Member States by rationalising health and safety compliance costs. ${ }^{39}$ Yet this is not

\footnotetext{
${ }^{30}$ AC Neal, "The European Framework Directive on the Health and Safety of Workers: Challenges for the United Kingdom” (1990) 6(2) The International Journal of Comparative Labour Law and Industrial Relations 80, 83-85.

${ }^{31}$ C Barnard, supra, note 17, p. 563.

32 For an indicative list see: European Agency for Safety and Health at Work, "Legislation" $<$ https://osha.europa.eu/en/legislation/directives/all $>$ (last accessed 2 July 2020).

33 J Kenner, supra, note 16, p. 95.

${ }^{34}$ Ibid.

${ }^{35}$ C Barnard, supra, note 17, pp. 507-510.

${ }^{36}$ Council Regulation (EC) No. 2062194 of 18 July 1994 establishing a European Agency for Safety and Health at work.

37 Art. 31(1) Charter of Fundamental Rights of the EU (CFREU), alongside the more specific provision on working hours in Art. 31(2) thereof.

${ }^{38}$ Principle 10(1) European Pillar of Social Rights.

${ }^{39}$ AC Neal and FB Wright, supra, note 20, pp. 13-14; Barnard, supra, note 17, p. 501.
} 
the sole reason why health and safety legislation flourished. A rigorous health and safety regime in the workplace reduces business costs and at the same time improves industrial relations.$^{40}$ In addition, it is bound to ameliorate the quality of life throughout the EU and takes on a preventative role of averting disasters of various natures. ${ }^{41}$ The latter two reasons showcase the area's public health ramifications and potential.

Nowadays, the enactment of measures in the context of health and safety in the workplace may be underpinned by a plethora reasons, going hand in hand with the Member States' contemporary realities. After all, occupational health and safety does not belong to the economic rationale of EU action. ${ }^{42}$ Although social policies, occupational health and safety included, were left to the internal market and the Member States, it was later on realised that further EU intervention under a social rationale that aimed to improve protection levels was needed. ${ }^{43}$ Consequently, an evolutionary process in the rationale of EU intervention in the field can be identified, wherein public health considerations linked to the protection of the workforce and the externalities associated with it take centre stage, especially in light of the ongoing pandemic. The clusters of Covid-19 infections constantly emerging in big workplaces are a testament to that, turning the protection of occupational health and safety into a public health matter without renouncing its social nature.

\section{Occupational Health and Safety and Covid-19}

It is important to dig deeper into the ways in which the health and safety acquis can protect the European workforce. The foregoing analysis made it clear that the centre of gravity for EU health and safety at work continues to be the Framework Directive, accompanied by its daughter Directives, soft-law initiatives and an emerging, though light-touch, rights-based approach. The employer, employees and national authorities all share responsibilities in this context. However, most duties fall on the employers, the stronger party in the employment relationship, who have to bear most risks as a consequence of them profiting from the labour of their workforce. ${ }^{44}$ Starting with the Framework Directive, the various duties of the employer outlined above apply and are relevant in the Covid-19 context. Employers ought to show awareness of the changing circumstances, take appropriate action, planning and risk assessment, offer training, involve their workers in the decision-making, as well as keep records. ${ }^{45}$ All are crucial in order to frame a concerted effort to guarantee occupational health and safety.

The duties placed on the employer by the Framework Directive are quite expansive and involve the adoption of preventive measures. ${ }^{46}$ More specifically, the second subparagraph of Article 6(1) thereof resonates today: 'the employer shall be alert to the need to adjust these measures to take account of changing circumstances and aim to improve existing situations'. This, coupled with the enumeration of nine principles of prevention that follows, showcases that employers must be alert and adjust workplace practices accordingly, in order to minimise the

\footnotetext{
${ }^{40}$ Ibid.

${ }^{41}$ Ibid.

${ }^{42}$ P Syrpis, EU Intervention in Domestic Labour Law (Cambridge, Cambridge University Press 2007) pp. 5556.

${ }^{43}$ Ibid, pp. 61-63. Syrpis singles out the entry into force of the then Art 118a EC under the Single European Act as an example of the social rationale's emergence.

${ }^{44}$ P Davies, "Posted Workers: Single Market or Protection of National Labour Law Systems?" (1997) 34(3)

Common Market Law Review 571, 597-598.

${ }^{45}$ Arts. 5 to 12 Directive 89/391/EEC. AC Neal, supra, note 31.

${ }^{46}$ Art. 6 Directive 89/391/EEC.
} 
risk of their workers contracting and spreading Covid-19. Indeed Article 6(3)(a) corroborates that employers have to consider all risks to health and safety in the workplace (emphasis added). ${ }^{47}$ Adaptations in workplaces where there is a clear risk of Covid-19 transmission are, therefore, stipulated by the Framework Directive.

The obligations of the Framework Directive are further fleshed out in the daughter Directives. Of those, Directives 89/656/EEC and 2000/54/EC are particularly relevant. The former covers the use of PPE, which is mandated if other measures and work patterns cannot eradicate the health and safety risk in question. ${ }^{48}$ There is a specific obligation upon the employer to provide for such equipment, ${ }^{49}$ compliant with EU standards, ${ }^{50}$ although there are exceptions for certain sectors. ${ }^{51}$ Nevertheless, great emphasis is placed on the Member States as they must lay down rules regarding the use of PPE and frame the employer's obligation. ${ }^{52}$ This is in line with the minimum standard-setting character of the Directive as a measure belonging to the social dimension of the EU. An argument could be made to the extent that employers ought to offer Covid-19 PPE, and national legislation could be interpreted or amended in that regard. However, this is likely to take time. In the meantime, protection could still be afforded under the more general -in scope and framing-Framework Directive.

The fellow daughter Directive on the protection from biological agents at work adopts a pattern of more extensive employer's obligations, mirroring those of the Framework Directive. ${ }^{53}$ Of relevance to Covid-19 are the reduction of risks; the information and notification of the competent authorities and the maintenance of a list of exposed workers; the hygiene and protection of workers, including PPE; information and consultation. ${ }^{54}$ Furthermore, there are specific measures for health care and industrial processes, laboratories and animal rooms, ${ }^{55}$ which include explicit containment measures. ${ }^{56}$ Biological agents are classified in risk groups, ranging from $1-4$, according to their severity. ${ }^{57}$

The classification of a biological agent to a risk group happens at EU level, through their inclusion in Annex III to the Directive. ${ }^{58}$ In June 2020, Covid-19 was added to Annex III as a group 3 agent through the amending Directive (EU) 2020/739, with an implementation deadline falling on 24 November $2020 .^{59}$ Interestingly, there were arguments, now dismissed, for Covid-19 to be classed in group 4 due to the lack of effective treatment or vaccine, which

\footnotetext{
${ }^{47}$ Confirmed by the CJEU in Case C-49/00, Commission v Italy [2001] ECLI:EU:C:2001:611, para. 12.

${ }^{48}$ Art. 3 Council Directive 89/656/EEC of 30 November 1989 on the minimum health and safety requirements for the use by workers of personal protective equipment at the workplace.

${ }^{49}$ Arts. 4 and 5 Directive 89/656/EEC.

${ }^{50}$ E.g. Regulation (EU) 2016/425 of 9 March 2016 on personal protective equipment.

51 Art. 2(2) Directive 89/656/EEC.

52 Art. 6 Directive 89/656/EEC. This is accompanied by indicative annexes at the end of the Directive.

${ }^{53}$ Directive 2000/54/EC of the European Parliament and of the Council of 18 September 2000 on the protection of workers from risks related to exposure to biological agents at work, which codified Directive 90/679/EEC.

${ }^{54}$ Arts. 6 to 13 Directive 2000/54/EC.

${ }^{55}$ Arts. 15 and 16 Directive 2000/54/EC.

${ }^{56}$ Annex V Directive 2000/54/EC includes a list of containment measures for risk groups 2-4, varying per group. ${ }^{57}$ Art. 2 Directive 2000/54/EC.

${ }^{58}$ Art. 18 Directive 2000/54/EC. Although, according to Art 18(2) Member States could classify the biological agent themselves pending Community action.

${ }^{59}$ Art. 3 Commission Directive (EU) 2020/739 of 3 June 2020 amending Annex III to Directive 2000/54/EC of the European Parliament and of the Council as regards the inclusion of SARS-CoV-2 in the list of biological agents known to infect humans and amending Commission Directive (EU) 2019/1833.
} 
would have required stringent compliance and containment measures. ${ }^{60}$ The alleged downplaying of Covid-19 in its categorisation, as well as the need for an implementation period that is still months away, may render the effectiveness of the amendments to the Biological Agents Directive questionable from a Social Europe or public health standpoint.

The Framework Directive and its daughter Directives overlap. The general duties of the former are given specific expression in the latter. Nonetheless, sometimes, the specific and technical character of the daughter Directives might mean that it is more difficult for them to adapt to emerging risks, such as those posed by Covid-19. The involvement of the Member States in updating technical and rigidly formulated domestic regulations implementing the Directives inevitably could slow down processes, as could the updating of Annexes to include Covid-19. Moreover, the scope of the daughter Directives might not be as crystal clear as first thought, leading to more contentious interpretations compared to the unequivocal wording of the Framework Directive that covers all risks. For instance, the containment measures of the Biological Agents Directive only apply to specific settings. ${ }^{61}$ Indisputably, containment measures are useful for areas of work more exposed to the risk of Covid-19, such as health care, but defining some of the other areas could prove difficult. ${ }^{62}$ That being said, the Biological Agents Directive's general provisions, allowing for health checks, should normally apply to every workplace where risk of contracting Covid-19 abounds. ${ }^{63}$ If only the implementation date for Covid-19's addition to Annex III was even shorter to better grapple with the magnitude -and pace- of a pandemic.

Apart from formal legislative action to include Covid-19 in the list of viruses covered by the Biological Agent Directive, guidance has been issued to adjust the EU occupational health and safety regime and practices to the new reality. This was spearheaded by the European Agency for Health and Safety at Work and includes general guidance for the workplace, ${ }^{64}$ as well as specific guidance for a safe return to work. ${ }^{65}$ A separate guidance for health care settings was issued by the European Centre for Disease Prevention and Control. ${ }^{66}$ These largely offer advice in accordance with the content of the afore-mentioned Directives. They showcase that the Directives' interpretation and application could be adapted without requiring formal changes to tackle the new threat. The guidance refers to social distancing, proper hygiene, testing and

60 ETUC, "ETUC note on Biological Agents Directive" $<$ https://www.etuc.org/sites/default/files/pressrelease/file/2020-05/20200429\%20ETUC\%20note\%20on\%20Biological\%20Agents\%20Directive.pdf $>$ (last accessed 8 July 2020).

${ }^{61}$ Arts. 15 and 16 Directive 2000/54/EC.

62 E.g. the concept of industrial processes. Although in relation to Covid-19, the Factsheet issued by the Commission clarifies adopting a strict interpretation that this refers to 'facilities that handle and manipulate samples of the virus, e.g. when producing a vaccine'. European Commission, 'Novel Coronavirus classified in biological agents directive to better protect health and safety of workers' $<$ https://ec.europa.eu/social/BlobServlet?docId=22729\&langId=en $>$ (last accessed 8 July 2020).

${ }^{63}$ Arts. 3 and 14 Directive 2000/54/EC.

${ }^{64}$ COVID-19: guidance for the workplace <https://oshwiki.eu/wiki/COVID-19: guidance for the workplace $>$ (last accessed 8 July 2020).

65 COVID-19: Back to the workplace - Adapting workplaces and protecting workers $<$ https://oshwiki.eu/wiki/COVID-19:_Back to the workplace -

Adapting_workplaces_and protecting_workers $>$ (last accessed 8 July 2020).

${ }_{66}$ Infection prevention and control and preparedness for COVID-19 in healthcare settings - fourth update

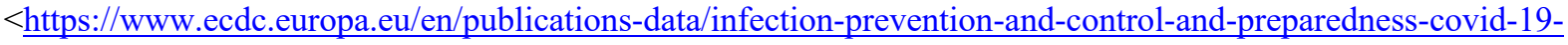
healthcare-settings $>$ (last accessed 8 July 2020). 
PPE, complemented by measures to safeguard mental health well-being. It is supported by additional ILO guidance along the same lines. ${ }^{67}$

A final note. Perhaps surprisingly, given the underlining of the right to 'a healthy, safe and well-adapted working environment' enshrined in Principle 10 of the Pillar to advocate for a short implementation period for Directive (EU) 2020/739, ${ }^{68}$ a rights-based approach is largely absent from the agenda. Even though it has been argued that workers shall enjoy a right to health and safety at work, it seems that such a debate has been neglected by the policymakers. ${ }^{69}$ Given that the right to healthy and safe working conditions is also protected under Article 31(1) CFREU, parallels emerge with the narratives surrounding the contested standing of the Charter's social provisions, ${ }^{70}$ and whether these could be relied on in horizontal situations. ${ }^{71}$ Not paying due regard to the Charter at policy level can only make things worse, since workers may lose additional ammunition of EU constitutional status in claims against their employers for inadequate protection from Covid-19.

\section{A European Health Union by Stealth?}

After having set out the content and context of the EU health and safety at work acquis, as well as its relevance to the fight against Covid-19, this section elaborates on its potential involvement in the formation of a European Health Union. There are varied views on the desirability and the ways to achieve a European Health Union, reflected in some of the contributions to the special issue. Section II of this article accentuated the indispensability of incorporating health and safety in the workplace among the areas comprising a widely construed European Health Union. Both narrow and broad definitions of occupational health and safety touch upon matters that can trigger spillover effects on public health. Diseases arising directly from work activities, or where the contribution of work to their transmission is significant, including those resulting in mild health problems, all showcase the salience of health and safety for the workforce. ${ }^{72}$ Vice-versa, a healthy workforce is an important aim for a European Health Union, for without one, there would be grave public health repercussions for the community.

At EU level, public health and occupational health and safety are formally viewed as separate areas at the moment. This could be attributed to their distinct competence regimes, public health having its own title in the TFEU, whereas occupational health and safety belongs to the Social Policy title. Although the EU Strategic Framework on Health and Safety at Work, talks

\footnotetext{
${ }^{67}$ International Labour Organization, In the face of a pandemic: Ensuring Safety and Health at Work (Geneva, ILO 2020).

${ }^{68}$ Preamble 8 to Directive (EU) 2020/739.

${ }^{69}$ K Lörcher, "Article 31 - Fair and Just Working Conditions", in Filip Dorssemont, Klaus Lörcher, Stefan Clauwaert and Mélanie Schmitt (eds), The Charter of Fundamental Rights of the European Union and the Employment Relation (Oxford, Hart Publishing, 2019) pp. 552-554.

${ }^{70}$ More specifically, the rights and principles debate. In relation to Art. 31(1) CFREU and whether it could be conceived as a justiciable right despite its general wording see: A Bogg "Article 31", in S Peers, T Hervey, J Kenner and A Ward (eds), The EU Charter of Fundamental Rights: A Commentary (Oxford, Hart Publishing 2014) pp. 849-850.

${ }^{71}$ E Frantziou, "(Most of) the Charter of Fundamental Rights is Horizontally Applicable: ECJ 6 November 2018, Joined Cases C-569/16 and C-570/16, Bauer et al" (2019) 15(2) European Constitutional Law Review 306.

${ }^{72}$ For the various definitions see: DG Employment, Social Affairs and Inclusion, Evaluation of the Practical Implementation of the EU Occupational Safety and Health (OSH) Directives in EU Member States (2015) VIIIX.
} 
about stronger cooperation with the stakeholders involved in public health, ${ }^{73}$ the so-called EU4Health Programme, whose proposal was unveiled at the end of May 2020 merely reiterates the same recommendation. From a public health perspective, too, it is important to engage with health and safety in the workplace. The EU4Health Programme might have been drafted in the shadow of Covid-19, but the only quasi-commitment to health and safety at work offered was the latter's mention in the actions that could be supported so as to strengthen the national health systems. ${ }^{74}$ The division appears to remain, defying any potential cross-fertilisation that Covid19 could have induced.

The EU competence on health has, similarly to Social Europe, been under a tremulous journey. Initially, even the inclusion of public health therein was debatable. ${ }^{75}$ This might be solved nowadays, but there is still no EU authoritative legislative provision defining public health, or even health for that matter. ${ }^{76}$ Nonetheless, it is widely accepted that EU public health refers to the management of collective health risks and the prevention of major disease scourges. ${ }^{77}$ Before its centre of gravity solidified in what is now Article 168 TFEU, public health was regulated indirectly at EU level mainly through the Common Agricultural Policy and the free movement of goods. ${ }^{78}$ Although harmonisation was excluded in the first incarnation of Article 168 under the Maastricht Treaty, ${ }^{79}$ assigning to the EU a largely coordinating role via the creation of programmes, subsequent amendments enabled the approximation of Member States' laws on the quality and safety of organs and substances, blood and its derivatives, medicinal products and devices, and other veterinary and phytosanitary measures, through instruments such as Directives and Regulations. ${ }^{80}$ However, these areas have little direct impact on the occupational health and safety acquis. ${ }^{81}$

With reference to the above, it becomes crucial to reiterate the need for a broad conceptualisation of the term European Health Union, so as to extend its scope beyond the EU's public health competence, by welcoming health and safety at work and other areas -when necessary- under its aegis. Apart from the symbolic gesture of breaking the barriers between inter-related areas and fostering a closer cooperation among the stakeholders involved therein more easily, putting health and safety at work in the driving seat for the creation of a European Health Union is likely to be beneficial in legal terms as well, since it would diversify the latter's toolkit. The EU public health competence was only introduced with the Treaty of Maastricht in 1993 and, even then, was rather modest in nature, barring harmonisation for the most part and containing rather weak provisions. ${ }^{82}$

\footnotetext{
${ }^{73}$ European Commission, Communication from the Commission to the European Parliament, the Council, the European Economic and Social Committee and the Committee of the Regions on an EU Strategic Framework on Health and Safety at Work 2014-2020 COM(2014) 332 final 15.

${ }^{74}$ European Commission, Proposal for a Regulation of the European Parliament and of the Council on the establishment of a Programme for the Union's action in the field of health -for the period 2021-2027 and repealing Regulation (EU) No 282/2014 (“EU4Health Programme") COM(2020) 405 final Annex I (g)(x).

75 TK Hervey and JV McHale, European Union Health Law: Themes and Implications (Cambridge, Cambridge University Press 2015) pp. 31-32.

${ }^{76}$ A de Ruijter, EU Health Law \& Policy: The Expansion of EU Power in Public Health and Health Care (Oxford, Oxford University Press 2019) pp. 55-57.

${ }^{77}$ Ibid, 62.

${ }^{78}$ Ibid, 64-69.

${ }^{79}$ Art. 129 EC.

${ }^{80}$ Art. 168(4) TFEU.

${ }^{81}$ K Lörcher, "Social Competences", in N Brrun, K Lörcher and I Schömann (eds), The Lisbon Treaty and Social Europe (Oxford, Hart Publishing 2012) p. 189.

82 TK Hervey and JV McHale, supra, note 76, p. 39.
} 
Although strengthened over time by the subsequent Treaty amendments, enabling EU (public) health law to make great advances, ${ }^{83}$ the stricto sensu public health competence of the Union is still limited. ${ }^{84}$ It has been propounded that a contextual, interrelated reading of the various legal bases touching on public and human health hints at the existence of more powerful competences than initially thought. ${ }^{85}$ Adding occupational health and safety into a wider European Health Union framework would legitimise the public health underpinnings of those actions that not only aim to promote worker protection but also the health and well-being of the whole population of the EU, through their preventative and safeguarding role. ${ }^{86}$ At the same time, it would expand the ambit of EU action in a broadly defined European Health Union, by making sure to allocate the appropriate expertise in initiatives spanning inter-related subfields, which do not belong to the delimited public health competence.

The flexibility of this approach, fostering synergy-building and cross-fertilisation among interdependent fields, would help achieve the creation of a European Health Union by stealth, avoiding complex discussions surrounding the formal expansion of the EU public health competence or a potential shake-up of the competence regime altogether. Finally, the diverse rationales underpinning social regulation, including in the area of occupational health and safety, would diminish the prevalence of a purely market-based perspective, which is dominant and governs hard law interventions within the EU public health policy, emancipating a future European Health Union from a similar trajectory.

To add to the arguments above, the degree of relevance as well as the achievability of a European Health Union solely on the basis of the EU's competence on public health alone remain uncertain. ${ }^{87}$ Occupational health and safety has enjoyed a longer-standing embeddedness in the Treaties, with a more far-researching development of actions allowed at EU level compared to public health. ${ }^{88}$ Even though it belongs to Social Europe, an area of haphazard commitment for further involvement, health and safety at work has been singled out as a force majeure of Social Europe, where social regulation through hard laws has been desirable, even without explicit competences initially. ${ }^{89}$ This has empowered legal integration therein, establishing strong path-dependence that legitimised the area, which has been accepted as such almost unchallengedly since the beginning of the EU project. ${ }^{90}$

Apart from the salience of occupational health and safety, its practical effectiveness in contributing to the establishing of a European Health Union makes it all the more pressing to openly include it as one of the concept's main drivers. Creative interpretations to advance public health might be tolerated in the current Treaty framework, but health and safety at work is already more intrinsically entrenched therein. Impediments to the approximation of health

\footnotetext{
${ }^{83}$ Ibid, pp. 42-53.

${ }^{84}$ Also asserted by the CJEU in the famous case of Case C-376/98 Federal Republic of Germany $v$ European Parliament and Council of the European Union (Tobacco Advertising) [2000] EU:C:2000:544.

${ }^{85}$ KP Purnhagen, A De Ruijter, ML Flear, TK Hervey and A Herwig, "More Competences than You Knew? The Web of Health Competence for European Union Action in Response to the COVID-19 Outbreak" (2020) 11 European Journal of Risk Regulation 297.

${ }^{86}$ See discussion in section IV.

${ }^{87}$ See articles by G Bazzan, T Venables and V Delhomme in this issue.

${ }^{88}$ See discussion in section III.

${ }^{89}$ G Majone, supra, note 19.

${ }^{90}$ See for example the unsuccessful challenge to the Working Time Directive by the UK: C-84/94 United Kingdom $v$ Council [1996] ECLI:EU:C:1996:431.
} 
policies could keep public health in the sphere of (new) intergovernmentalism. ${ }^{91}$ On the contrary, occupational health and safety with its long-standing minimum standard-setting approach across the EU has strong foundations to build on, that could have positive spillover effects on the health of the rest of the population. Moreover, its expansive scope, covering vulnerable workers in atypical employment relationships, means that health and safety at work can already protect certain groups of society without the need for further EU public health intervention..$^{92}$ On that note, let us recall that many of the recent Covid-19 outbreaks in Europe are linked to clusters in workplaces, pinpointing the importance of developing and better enforcing the occupational health and safety acquis. The latter figures among the most integrated aspects of Social Europe and could function as driver towards a European Health Union too, for the reasons stated supra. The two are not mutually exclusive.

\section{Occupational Health and Safety in a post-Covid world: Towards a European} Health Union

The preceding section established why occupational health and safety is not only desirable but beneficial to be taken into consideration in the conceptualisation of the European Health Union. Building on that, this section sets out a roadmap for the health and safety at work acquis, taking into account the issues that emerged and the lessons learned during the ongoing pandemic. Proposals by the EU institutions to reform EU health and safety at work legislation in light of Covid-19 have been muted. The only exception is the inclusion of Covid-19 in the list of biological agents, exposure to which is protected under the eponymous Directive. Given the wealth of the occupational health and safety acquis this is not surprising. Neither is it contemptible. There is enough social regulation and minimum standards-setting approximation for the area to flourish and develop as it stands. What is needed, instead, is better enforcement to maintain its efficiency and effectiveness. That way a strong constituent pillar of the European Health Union would materialise.

The formal categorisation of occupational health and safety under the social policy title lends itself to an uninterrupted melange of hard and soft law approaches alike. ${ }^{93}$ The emergence of a broadly construed European Health Union, which is more akin to an expansive framework, would enable synergies between public health and occupational health and safety narratives when needed. This is not novel, but draws on the long-standing interdependence between the areas. Public health rationales are in the forefront of the EU's strategy on biological agents and prevention of work-related diseases. ${ }^{94}$ Moreover, public health authorities are already involved in ensuring the implementation and enforcement of occupational health and safety legislation in some Member States. ${ }^{95}$ Having health and safety in the workplace normatively shared

91 CJ Bickerton, D Hodson and U Puetter, "The New Intergovernmentalism and the Study of European Integration", in CJ Bickerton, D Hodson and U Puetter (eds), The New Intergovernmentalism: States and Supranational Actors in the Post-Maastricht Era (Oxford, Oxford University Press 2015) p. 18.

${ }^{92}$ As a recent example, in July 2020 the Independent Workers Union of Great Britain has been granted permission to proceed with a judicial review of the applicable national laws on occupational health and safety by the High Court. IWGB argues that the national laws should be interpreted in line with the pertinent EU Directives, which they failed to implement properly, in order to extent the coverage of national legislation to gig workers in addition to employees. IWGB, High Court grants IWGB permission to challenge Health and Safety legislation (2020) $<$ https://iwgb.org.uk/post/high-court-health-safety $>$ (last accessed 12 July 2020).

${ }^{93}$ Indeed, Social Europe has proved a melting pot of integration styles and approaches. For more see: K Alexandris Polomarkakis, "Social Europe: A Midsummer Night's Dream?", in JP Cardwell and M-P Granger (eds), The Research Handbook on the Politics of EU Law (Cheltenham, Edward Elgar 2020) pp. 223-244.

${ }^{94}$ European Agency for Safety and Health at Work, Biological agents and prevention of work-related diseases: a review (Luxembourg, Publications Office of the European Union 2020).

${ }^{95}$ DG Employment, Social Affairs and Inclusion, supra, note 73, p. 152. 
between Social Europe and the European Health Union is, thence, likely to boost the quality of these proposals, by framing them in a way that simultaneously protects the workforce and the health of the wider population of the EU.

\section{Stronger Enforcement Mechanisms}

It is of paramount importance to ensure that the acquis on health and safety at work is actually enforced. If it is not, then problems like those described at the beginning of the article will emerge. The Commission diligently sought to secure the correct implementation of the pertinent Directives by the Member States. ${ }^{96}$ However, the role of enforcing their provisions domestically is left to national enforcement bodies. Often, but not always, these take the form of labour inspectorates. ${ }^{97}$ There are no stipulations as to the actual formation of those bodies, as it is a matter of national law, and this has resulted in enforcement and compliance problems. ${ }^{98}$ The only effort for such initiative at EU level is the recently inaugurated European Labour Authority. Nonetheless, the Authority has a limited scope and a rather soft coordinating role. It has some powers to undertake studies or flag up any potential health and safety risks, but only in the context of labour mobility. ${ }^{99}$ Even then, some instances might not be effectively protected, as the Covid-19 outbreaks that hit migrant agricultural workers in the EU showed. ${ }^{100}$

The above highlight the need to strengthen the monitoring mechanisms at EU level, by expanding the scope of the European Labour Authority, for example, even though one might argue that it is too soon for this to be successfully done to a rather new institution. An alternative would be the empowerment of the European Agency for Safety and Health at Work, to undertake some naming and shaming practices. To that regard, the launch of a health and safety Barometer in late May 2020 is a positive move. The addition to the Social Scoreboard initiated by the European Pillar of Social Rights, of indicators measuring health and safety at work could also help. ${ }^{101}$ Benchmarking would not only highlight the disparities among the EU27 and lead to peer pressure for enforcement, but it could also give enough evidence to the EU institutions that further actions regarding enforcement are needed.

The creation of a transnational European Labour Inspectorate is likely to be the most effective option, but there are doubts on how achievable this would be. The Senior Labour Inspectors' Committee, which already assists the Commission, could be strengthened to oversee not only the implementation of the EU occupational health and safety legislation, but also its enforcement by the national authorities. ${ }^{102}$ Notwithstanding the difficulties in establishing a transnational Labour Inspectorate at EU level, there have been proposals put forward discussing the desirability of an institution of that kind under the aegis of the ILO. ${ }^{103}$ Even if

\footnotetext{
${ }^{96}$ DG Employment, Social Affairs and Inclusion, supra, note 73, pp. 54-55.

${ }^{97}$ D Walters, 'Labour inspection and health and safety in the EU' (2016) 14 ETUI HesaMag 12.

${ }^{98}$ R Dukes, The Labour Constitution: The Enduring Idea of Labour Law (Oxford, Oxford University Press 2014) 179.

${ }^{99}$ Preamble 8 and Art. 10(1) Regulation (EU) 2019/1149 of the European Parliament and of the Council of 20 June 2019 establishing a European Labour Authority.

${ }^{100}$ R Creţan and D Light, "COVID-19 in Romania: transnational labour, geopolitics, and the Roma outsiders" (2020) Eurasian Geography and Economics Online First 5-6.

${ }^{101}$ Building on Regulation (EC) No 1338/2008 of the European Parliament and of the Council of 16 December 2008 on Community statistics on public health and health and safety at work.

${ }^{102}$ Commission Decision of 12 July 1995 setting up a Committee of Senior Labour Inspectors (95/319/EC).

103 A Garcia-Muñoz Alhambra, B Ter Haar and A Kun, "Harnessing Public Institutions for Labour Law Enforcement: Embedding a Transnational Labour Inspectorate within the ILO” (2020) 17(1) International Organizations Law Review 233.
} 
an EU-centred enforcement overseeing body would be preferable, the existence of a transnational Labour Inspectorate under the ILO could still help induce compliance. After all, ensuring standards consistent with ILO Conventions at EU level can be traced back to the European Coal and Steel Community. ${ }^{104}$

\section{Rights-based and Public Health Approaches}

The right to health and safety at work is protected under Article 31(1) CFREU as well as Principle 10 of the European Pillar of Social Rights. Enabling a rights-based approach to the area to flourish would add an extra layer to a European Health Union. New initiatives could be adopted under this narrative, overlapping with protection of other associated rights such as dignity. ${ }^{105}$ Furthermore, a rights-based approach encapsulates the element of universality in the protection of health and safety at work, evading the need to make recourse to the definition of worker, for example. On a different note, the recognition of a right to health and safety in the workplace can give rise to private enforcement by wronged members of the workforce that seek justice for inadequate protection against their employers. This could complement the public enforcement route, without requiring its overhaul. Despite the difficulties, outlined in section IV, in affirming a social right as fundamental, there is a tendency of gradual acceptance, which could be prompted further by the use of strategic litigation.

If the above seem unachievable, perhaps just adding to the discourse a new narrative might help. Focusing on the enforcement of health and safety at work as a matter of public health could raise awareness of the salience of its protection and enforcement at national level. ${ }^{106}$ Moreover, a public health approach to the litigation of occupational health and safety is likely to render the latter a more integral part of a European Health Union symbolically, at least insofar as the traditional understanding of it is concerned. Law-making and jurisprudential accounts that frame aspects of public health as human rights are much more prevailing, and could, thus influence the development of the occupational health and safety acquis. ${ }^{107}$ Conceptualising Article 31 CFREU as a social determinant of public health ${ }^{108}$ could support EU health and safety at work legislation to overcome the constraints imposed by the reluctant approach of the CJEU to areas belonging to Social Europe. Eventually, the public health dimension of a provision might carry more weight over other aspects of European integration, especially during a pandemic. Thus, adopting this approach could provide the right impetus for comprehensive action regarding occupational health and safety and cement its place in the cadre of a European Health Union.

\section{Collective Bargaining}

Information and consultation of workers and their representatives are inherent components of almost all the occupational health and safety acquis. Indeed, the Commission has emphasised the importance of workers' voice for the area. ${ }^{109}$ In addition, social dialogue is implicated in

\footnotetext{
${ }^{104} \mathrm{~J}$ Kenner, supra, note 16 , pp. 54-55.

105 K Lörcher, supra, note 70, pp. 537-538.

${ }^{106}$ For the merits of a public health approach to discrimination law see: I Solanke, Discrimination as Stigma: A Theory of Anti-discrimination Law (Oxford, Hart Publishing 2017).

107 TK Hervey and JV McHale, supra, note 76, 41-42.

${ }^{108}$ With reference to the table in A de Ruijter, "The impediment of health laws' values in the constitutional setting of the EU", in TK Hervey, CA Young, LE Bishop (eds), Research Handbook on EU Health Law and Policy (Cheltenham, Edward Elgar 2017) pp. 188-189.

${ }^{109}$ Commission communication for the implementation of Council Directive 89/656/EEC of 30 November 1989 (1989) 89/C 328/02.
} 
labour law and social policy-making under Articles 154 and 155 TFEU. Often, negotiated framework agreements form the backbone of EU social legislation. Nevertheless, this is not always the case. Progress on enacting EU legislation on the basis of the sectoral agreement on health and safety of hairdressers, for example, has stalled. ${ }^{110}$ Therefore, there could be instances where either the Commission does not pick up on the agreement, or the employers' side does not wish to negotiate certain matters. Inevitably, this could jeopardise social dialogue on aspects of occupational health and safety as well.

Despite these obstacles, workers' voice and collective bargaining can exert important influence on the enforcement and interpretation of the health and safety at work acquis, and shape, even through mere suggestions, the direction of future action in the area. This is evident in the emergence of transnational company agreements, a form of international agreement of voluntary nature that sometimes touch upon health and safety at work. ${ }^{111}$ Institutional or voluntary, the role of collective bargaining is crucial in framing the debate and supporting actions in the area. As Dukes notes, "without any or with only a muted voice at work, workers will become ever more vulnerable to unfair or harsh treatment, to abuses of their remaining rights and of health and safety standards'. ${ }^{112}$ Given the interdependence between occupational health and safety and public health, the amplification of workers' voice should be nurtured in the context of a European Health Union too.

\section{Swift Amendment Processes}

The general wording and nature of the Framework Directive, complemented by its daughter Directives, ensures resilience and adaptability to new challenges, including the emergence of a pandemic. That notwithstanding, and if reliance on the pre-existing acquis is the preferred option, then some tighter implementation deadlines shall be in order, insofar as the amendment of a specific daughter Directive is concerned, so as to include a new threat. Leaving Member States 5 months to implement the addition of Covid-19 to Annex III, in the context of the Biological Agents Directive is not swift enough to catch up with the risks associated with a new pandemic. Understandably, the formal law-making processes in 27 Member States need to be taken into account, and some might be slower than usual given the circumstances, but even then, a 5-month implementation period risks adulterating the effective application of the proposed reforms. In other words, it is essential for compliance to be triggered quickly, to keep pace with the ever-changing realities of a pandemic. Thankfully, the occupational health and safety acquis is rich enough to enable an expansive interpretation of its provision to lay down protection mechanisms against the risks of Covid-19 in the workplace and wider society, even without the virus's formal inclusion in a pertinent Directive. Yet, for specific measures under some technical daughter Directives, the explicit addition of Covid-19 might be necessary, hence why tighter deadlines are desirable.

\section{Further reforms}

The occupational health and safety acquis might be resilient and malleable enough to withstand quick adaptations to tackle pandemics, but that does not mean that it is faultless. Psycho-social

\footnotetext{
${ }^{110}$ P de Buck and M Cerutti, "Social Dialogue: Why It Matters - European Employers' Perspective", in F Vandenbroucke, C Barnard and G De Baere (eds), A European Social Union after the Crisis (Cambridge, Cambridge University Press 2017) p. 228.

${ }^{111}$ R Dukes and C Cannon, "The role of social partners", in A Bogg, C Costello and ACL Davies (eds), Research Handbook on EU Labour Law (Cheltenham, Edward Elgar 2016) pp. 105-110.

${ }^{112}$ R Dukes, supra, note 9, p. 192.
} 
risks associated with the mental well-being of the workforce, triggered by the fear of the virus, coupled with the prolonged confinement at home or extra hours at work, could have longlasting effects to the health of the workforce. The area has attracted the attention of the Commission already, but stronger actions could be taken in that regard. This would ensure a balanced development of both narrow and broad understandings of occupational health and safety, true to the premise of a European Health Union. In addition, reforms could aim at upping the protection offered in line with the principles of the Pillar, similar to the recent Work-Life Balance Directive. ${ }^{113}$ This would also align with the paradigm of social sustainability for the EU. ${ }^{114}$ If enforcement becomes more stringent, and financial losses due to an exposed workforce mount, employers and their representatives might have a strong incentive to agree on more far-reaching preventive measures.

VII. Conclusion

Health and safety at work has had immense coverage during the ongoing pandemic. Shortcomings in its protection led to new spikes and exposed bleak working conditions, despite the existence of comprehensive legislation at EU and national level. Emerging talks about creating a European Health Union should pay due attention to this area, especially if the term is to be emancipated from an exclusive association with the EU public health competence. This article traced the roots of European health and safety in the workplace and established its salience in keeping a healthy population and containing a pandemic alike. More than that, it contended that focusing on occupational health and safety is desirable if a European Health Union is to flourish. Finally, it set out suggestions on how to develop the occupational health and safety acquis as a core component of a European Health Union, reflecting on the experience from the handling of Covid-19.

It is rather intriguing that a quintessential area of Social Europe could move to the forefront and lay the groundwork for a European Health Union. It is a true testament to Social Europe's -and occupational health and safety's in particular- evolutionary rationales for EU intervention, which have come to incorporate public health considerations. Path-dependence, associated with legal integration, and a wide scope with positive spillover effects confirm that looking at health and safety at work interventions should be prioritised in that context, not at the expense of but alongside traditional public health strategies. Oscillating between Social Europe and public health, occupational health and safety deserves to be one of the main pillars of the European Health Union edifice, to give the latter a genuinely fully-fledged character. Covid19 , similar to occupational health and safety disasters in the past, is likely to cement political support towards the creation of a European Health Union. ${ }^{15}$ It may as well prompt the consideration of occupational health and safety as a constituent element of the latter's emerging framework, allowing for cross-fertilisation between the social and public health spheres of the EU project.

\footnotetext{
${ }^{113}$ Directive (EU) 2019/1158 of the European Parliament and of the Council of 20 June 2019 on work-life balance for parents and carers and repealing Council Directive 2010/18/EU.

${ }^{114}$ K Alexandris Polomarkakis, "The European Pillar of Social Rights and the Quest for EU Social Sustainability" (2020) 29(2) Social \& Legal Studies 183.

${ }^{115}$ AC Neal and FB Wright, supra, note 20, p. 2.
} 